ГЕОЭКОЛОГИЧЕСКИЕ ПРОБЛЕМЫ ТЕРРИТОРИЙ НЕФТЕДОБЫЧИ

\author{
Дитц Л.Ю., Дудина Т.Н., Цускман Е.И., Катункина Е.В. \\ ФГБОУ ВО «Новосибирский государственный университет экономики и управления», \\ Новосибирск, е-mail: l.ditz@mail.ru
}

\begin{abstract}
В статье рассмотрены геоэкологические проблемы загрязнения болотных комплексов территории Варынгского нефтяного месторождения ХМАО. Большинство технологических площадок нефтяных месторождений расположены на олиготрофных болотах, которые защищают природные и межпластовые воды от проникновения химических загрязнителей. Дана характеристика источникам поступления химических элементов, к которым относятся кустовые площадки эксплуатационных скважин, буровые шламовые амбары и нефтегазопроводы. К основным загрязнителям относятся нефть и нефтепродукты, пластовые воды, буровые шламовые растворы, технологические жидкости. Основной причиной засоления болот являются неконтролируемый сброс высокоминерализованных пластовых вод и аварийные выбросы буровых шламовых растворов при разведывательном нефтяном бурении скважин. Проведенный анализ поведения биоиндикаторов (мхи, лишайники) позволил установить основные зоны засоления. Было выявлено, что на участках среднего и сильного засоления ионами хлора и натрия отмечается гибель болотной растительности. Особое внимание уделено проблемам аварийных разливов нефти и нефтепродуктов. В состав нефтепродуктов входят низкомолекулярные метановые углеводороды, нафтеновые и ароматические углеводороды, асфальтены и нефтяные смолы. Негативное влияние нефтезагрязнения оценивается по содержанию в нефти тяжелых металлов. Экологическую опасность представляют последствия сжигания разливов нефти, в результате чего повышаются токсичные концентрации ванадия, никеля, бензапирена, кадмия, бериллия, мышьяка, марганца, свинца. К перспективным методам снижения негативного воздействия при разработке нефтяных месторождений относятся безамбарный способ бурения эксплуатационных скважин, использование малотоксичных реагентов. Для восстановления нефтезагрязненных земель и восстановления фитоценозов возникает необходимость внедрения альтернативных технологий для активизации процессов метаболизма.
\end{abstract}

Ключевые слова: нефтедобыча, кустовые площадки, буровые скважины, шламовые амбары, источники загрязнения, засоление, тяжелые металлы

\title{
GEOECOLOGICAL PROBLEMS OF OIL PRODUCTION TERRITORIES
}

Ditz L.Yu., Dudina T.N., Tsuskman E.I., Katunkina E.V.

\author{
Novosibirsk State University of Economics and Management, Novosibirsk, e-mail: l.ditz@mail.ru
}

\begin{abstract}
The article considers the geoecological problems of pollution of wetland complexes in the territory of the Varyngsky oil field of the Khanty-Mansi Autonomous Okrug. Most of the technological platforms of oil fields are located on oligotrophic bogs, which protect natural and interstratal waters from the penetration of chemical pollutants. The characteristic is given to the sources of supply of chemical elements, which include wellbores of production wells, drill cuttings and oil and gas pipelines. The main pollutants include oil and petroleum products, produced water, drilling mud, and process fluids. The main reason for salinization of the marshes is the uncontrolled discharge of highly mineralized formation water and accidental discharges of drill cuttings during exploratory oil drilling. The analysis of the behavior of bioindicators (mosses, lichens) made it possible to establish the main salinization zones. It was found that in areas of moderate and severe salinization by chlorine and sodium ions, the death of marsh vegetation is noted. Particular attention is paid to the problems of emergency oil and oil product spills. The composition of petroleum products includes low molecular weight methane hydrocarbons, naphthenic and aromatic hydrocarbons, asphaltenes and petroleum resins. The negative effect of oil pollution is estimated by the content of heavy metals in the oil. The consequences of burning oil spills pose an environmental hazard, resulting in increased toxic concentrations of vanadium, nickel, benzapyrene, cadmium, beryllium, arsenic, manganese, and lead. Promising methods for reducing the negative impact in the development of oil fields include the pitless method of drilling production wells, the use of low-toxic reagents. To restore oil-contaminated lands and restore phytocenoses, it becomes necessary to introduce alternative technologies to activate metabolic processes.
\end{abstract}

Keywords: oil production, well pads, boreholes, sludge pits, pollution sources, salinization, heavy metals

На территории Россия сосредоточено около $8 \%$ мировых запасов нефти, из которых почти две трети находятся в Западной Сибири. Добыча нефти и газа в Западной Сибири несет в себе потенциальную опасность катастрофического нарушения состояния крайне ранимой и неустойчивой к техногенному воздействию природной среды её северных районов [1]. Разведка, добыча и транспортировка нефтепродуктов являет- ся основной причиной деградации и загрязнения болотных геосистем.

Нефтяная и газовая промышленность, являясь составной частью топливно-энергетического комплекса, представляет собой сложную отрасль производства. Наряду с качественным истощением минеральных ресурсов нефтедобывающие комплексы являются источниками повышенной экологической опасности [1]. 
Географической особенностью ландшафтов северных районов Западной Сибири является широкое распространение болотных комплексов. Болота занимают обширные водоразделы, террасы и ступени рельефа, долины местных рек. Большая часть из них представлена мерзлыми торфяниками с лишайниковым покровом плоских бугров и мезоолиготрофными осоково-сфагновыми сообществами мочажин. В природоохранном и ресурсном аспекте наличие многолетней или сезонной мерзлоты препятствует поступлению нефтяных и солевых загрязнений в водоносные горизонты грунтовых и межпластовых вод. Поэтому в районах нефтедобычи с высоким процентом заболоченных земель техногенное воздействие требует тщательного изучения с позиций экологии и охраны недр.

Изучение геохимического состояния природных сред в районах нефтедобычи имеет большое как теоретическое, так и практическое значение.

Объектом исследования является территория месторождения нефти «Варынгское», расположенная в северной части Нижневартовского района Ханты-Мансийского автономного округа. Площадь территории составляет 157,5 км² $^{2}$.

Воздействие нефтегазовой промышленности на природные экосистемы в пределах территории данного месторождения было рассмотрено на локальном уровне, так как экосистемы испытывают негативное влияние не всей нефтедобывающей промышленности, а только какого-то конкретного ее проявления.

Разработка нефтяных месторождений приводит к негативной трансформации ландшафтов. Экологическую опасность загрязнения территории представляют промышленные объекты нефтегазодобывающих комплексов, к которым относятся буровые площадки, нефтепроводы, буровые шламовые амбары.

Целью исследования является оценка воздействия буровых шламовых растворов, в состав которых входят водно-солевые смеси, и аварийных разливов нефти, содержащей большое количество ароматических углеводородов и тяжелых металлов, на болотные экосистемы кустовых участков нефтедобычи.

В настоящей работе ставилась задача оценить экологические последствия влияния химических загрязнений на состояние болотных комплексов.

\section{Материалы и методы исследования}

Загрязнение техногенными продуктами было выявлено почти на всех технологических этапах нефтедобычи, которые отличаются масштабами и интенсивностью нарушений, содержанием и токсичностью химических элементов.

Основными загрязнителями являются нефть и нефтепродукты, пластовые воды, буровые шламовые растворы, химические реагенты. В зоне нефтедобычи севера Западной Сибири еще одним источником минеральных элементов на торфяных болотах являются технологические жидкости [2].

Большинство технологических площадок расположено на олиготрофных грядово-мочажинных болотах. Детальное обследование месторождения выявило локальные участки разливов нефти площадью менее 1 га, которые приурочены к буровым площадкам.

Для выявления степени негативного воздействия был проведен отбор проб природных и загрязненных вод вблизи кустовых площадок разведывательного и эксплуатационного бурения, а также растительных проб торфов на содержание тяжелых металлов. Образцы воды для анализа загрязненных вод отбирались в экосистемах, окружающих источники загрязнения, и в самих источниках загрязнения.

\section{Результаты исследования и их обсуждения}

Отрицательное влияние на окружающую среду оказывают производственнотехнологические отходы бурения. В процессе бурения эксплуатационных скважин буровые растворы используются для создания пластового давления. Химические добавки и реагенты, содержащиеся в буровых растворах, по степени токсичности относятся к IV классу опасности [3].

Отработанные буровые растворы и сточные буровые воды поступают в амбары-накопители, или шламовые амбары. Шламовые амбары устраиваются в углублениях песчаной насыпи кустовых площадок без гидроизоляции (рис. 1). Амбары являются открытыми водно-солевыми системами. Наряду с отработанными буровыми растворами пополнение солевых запасов происходит в результате поверхностного стока с кустовой площадки и сброса продукции скважин при их технологическом обслуживании [4]. Удаление солей из амбаров происходит в результате вертикальной и боковой фильтрации, сброса воды при прорыве обваловки. 


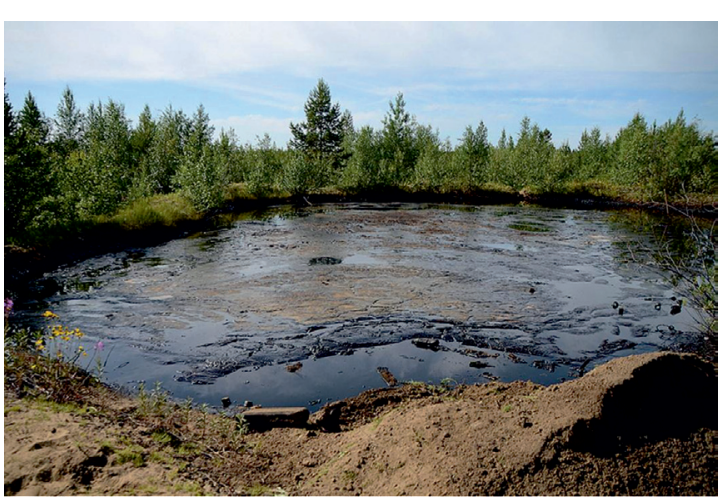

Рис. 1. Шламовый амбар без гидроизоляциии

Шламовые амбары, сооруженные для хранения отходов бурения в течение длительного времени, являются источником повышенной опасности для окружающей среды. Поступление токсичных веществ из шламовых амбаров, в которых скапливаются отходы бурения, является причиной отсутствия гидроизоляционной прослойки.

Непосредственную экологическую опасность представляют высокоминерализованные нефтяные и пластовые воды. Главной причиной засоления территории концентрированными пластовыми водами на кустовых площадках являются неконтролируемый сброс минерализованных попутных пластовых вод (5-80 г/л) и аварийные выбросы буровых шламовых растворов при разведывательном нефтяном бурении скважин.

Благодаря хорошей водопроницаемости верхних слоев торфяных почв пластовые воды свободно растекаются по окружающей территории. Дальность рассеивания солей зависит от многих факторов: времени объема выброса, геоморфологических условий, направления и скорости потока болотных вод. По мере продвижения солевого потока концентрация солей уменьшается в результате смешивания с ультрапресными фоновыми болотными водами и атмосферными осадками, что приводит к образованию обширных очагов загрязнения с различной степенью засоления.

Болотные почвы территории неустойчивы к химическому загрязнению и способны аккумулировать такие загрязнители, как $\mathrm{Na}^{+}, \mathrm{K}^{+}, \mathrm{Ca}^{2+}, \mathrm{Mg}^{2+}, \mathrm{Cl}^{-}$и $\mathrm{HCO}_{3}$ которые попадают в торф с буровыми растворами и подземными засоленными водами [5].

Химический состав пластовых вод имеет ряд характерных особенностей. В составе солей практически отсутствуют сульфаты. Степень засоления буровыми и пластовыми водами определяется в основном содержанием ионов хлора и натрия (табл. 1). На их долю приходится 95\% солевого состава.

Проведенный сравнительный анализ химического состава природных и техногенно загрязненных вод выявил изменение реакции среды при разливе буровых растворов или пластовых вод. Если в незагрязненных аналогах реакция среды $(\mathrm{pH})$ в основном слабокислая $(4,6-5,7)$, то в техногенно загрязненных пробах $\mathrm{pH}$ с поверхности и до глубины 50 см изменяется до щелочных показателей $(7,6-8,3)$.

Хлоридно-натриевое засоление оказывает токсичное действие на состояние растительного покрова. На участках сильного засоления отмечается гибель растительности олиготрофных болот, которая адаптирована к ультрапресным природным водам.

Таблица 1

Сравнительный анализ природных и техногенных вод (источников солей), мг/л

\begin{tabular}{|c|c|c|c|c|c|c|c|c|}
\hline & $\mathrm{pH}$ & $\mathrm{HCO}_{3}^{-}$ & $\mathrm{Cl}^{-}$ & $\mathrm{SO}_{4}^{-}$ & $\mathrm{Ca}^{++}$ & $\mathrm{Mg}^{++}$ & $\mathrm{Na}^{+}$ & $\mathrm{K}^{+}$ \\
\hline \multirow{5}{*}{ Природные воды } & 5,7 & 19,91 & 5,16 & 7,44 & 1,28 & 0,19 & 1,00 & 0,54 \\
\cline { 2 - 9 } & 4,6 & 3,95 & 2,62 & 2,59 & 0,83 & 0,19 & 0,79 & 0,64 \\
\cline { 2 - 9 } Техногенные воды & 4,9 & 3,99 & 2,39 & 2,67 & 0,78 & 0,11 & 0,62 & 0,47 \\
\hline & 8,1 & 192,3 & 8917,6 & 0,4 & 290,0 & 55,5 & 5250,0 & 51,0 \\
\cline { 2 - 9 } & 7,6 & 175,7 & 8502,2 & 0,2 & 285,0 & 51,0 & 5150,0 & 40,0 \\
\cline { 2 - 9 } & 8,2 & 122,0 & 9762,5 & 1,1 & 340,0 & 55,0 & 5850,0 & 61,0 \\
\cline { 2 - 9 } & 7,9 & 87,8 & 12780,0 & 87,8 & 440,0 & 86,0 & 7500,0 & 85,0 \\
\cline { 2 - 9 } & 8,2 & 107,4 & 2967,8 & 3,5 & 110,0 & 15,0 & 1825,0 & 20,0 \\
\cline { 2 - 9 } & 8,0 & 183,0 & 155,0 & 20,2 & 24,0 & 2,4 & 144,0 & 11,2 \\
\cline { 2 - 8 } & 8,3 & 378,0 & 404,0 & 12,5 & 25,6 & 11,7 & 375,0 & 13,0 \\
\hline & 8,1 & 256,0 & 290,0 & 18,5 & 21,9 & 7,8 & 260,0 & 12,4 \\
\hline
\end{tabular}


Более чувствительными к щелочному загрязнению являются верховые торфяники, сфагновые мхи и лишайники. С этой целью, для выявления локальных очагов загрязнения и переноса загрязняющих веществ на большие расстояния, проводится анализ количественного и качественного состава биоиндикаторов (растений, мхов и лишайников) и концентрации в них загрязнителей. На болотах происходит снижение роли сфагновых мхов и мохового покрова в целом, возрастает роль осоковых, главным образом пушиц, из которых на наиболее минерализованных субстратах преобладает Eriophorum scheuchzerii, происходит внедрение аллювиафильных видов (ивы, вейники, хвощи, ситники) и сорных заносных видов, среди которых самыми заметными постепенно становятся виды рогоза.

Повышенная концентрация солей и нефтепродуктов в торфяниках отмечается на расстоянии 5-10 метров от источников загрязнения за счет перемещения их по цепочке болотных озер и мочажин.

Высокую потенциальную опасность представляют аварийные разливы нефти и нефтепродуктов в результате порывов нефтепроводов.

При попадании нефти на поверхность торфяника происходит заполнение мочажин и пониженных элементов рельефа, а также небольших озер и ручьев (рис. 2).

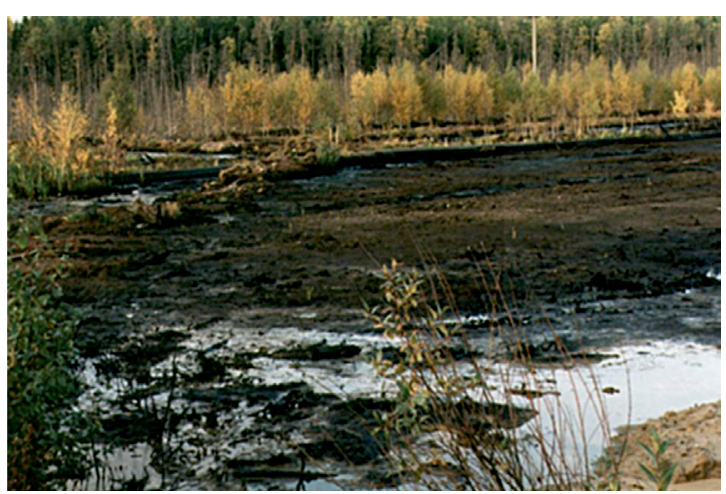

Рис. 2. Аварийный разлив нефти на заболоченном участке

Нефть состоит из фракций, которые обладают различной подвижностью и степенью токсичности. Подвижная часть нефти включает простые по строению низкомолекулярные углеводороды, парафиновые и ароматические углеводороды. При массивном разливе нефти (более 10 л/м²) на загрязненной территории наиболее чувствительные к солнечному излучению легкие фракции нефти подвергаются фотохимическому разложению.

На глубине 20-40 см накапливаются низкомолекулярные метановые углеводороды и более устойчивые циклопарафины, нафтеновые и ароматические углеводороды, асфальтены и нефтяные смолы [6].

Основные физико-химические свойства ароматических углеводородов определяют асфальтены и смолистые соединения, которые содержат большое количество тяжелых металлов (Co, Pb, Mn, Cu, V, As, Hg, Mo).

Исходя из особенностей химического состава нефтяных фракций, особое внимание было уделено содержанию тяжелых металлов.

Негативное изменение экологической обстановки на нарушенных территориях оценивалось по содержанию тяжелых металлов, которые при высоких концентрациях оказывают токсичное действие на биоценозы (табл. 2).

По данным табл. 2, распределение и количество элементов зависит от временного фактора. Высокое содержание элементов в пробе 1, особенно в слое 0-10 см, свидетельствует о накоплении смолистых и нафтеновых соединений на поверхности свежего нефтяного разлива. Через 3 месяца после аварийного разлива в пробе 2 отмечается наибольшее содержание тяжелых металлов уже на глубине 10-20 см, что свидетельствует о частичном разложении тяжелых фракций нефти и перемещении их вниз по профилю. Невысокое содержание тяжелых металлов в пробе 3 значительно меньше, так как отбор был проведен через 1 год после аварийного разлива. Это явление вызвано, по мнению многих исследователей, восстановлением и усилением микробиологической активности деструкторов.

Согласно проведенным исследованиям, ведущими загрязнителями болотных комплексов являются $\mathrm{Ba}, \mathrm{Mn}$ и $\mathrm{Sr}$, относящиеся к 3 классу опасности. Их концентрация в загрязненном торфе, по сравнению с другими элементами, значительно выше остальных элементов. Перечисленные элементы являются основными загрязнителями природной среды при нефтедобыче. При извлечении на поверхность все они способны к избыточному накоплению в объектах природной среды - почвах и водах. Происходит нарушение сложившегося биогеохимического цикла элементов в ландшафтах, а в катастрофических случаях - гибель растительных и животных организмов, деградация почв и водоемов. Самовосстановление экосистем на таких участках наиболее длительно. 
Таблица 2

Содержание тяжелых металлов в загрязненном торфе в слое 0-10, 10-20 см, мг/кг

\begin{tabular}{|c|c|c|c|c|c|c|c|c|c|c|c|c|}
\hline & $\mathrm{Mn}$ & $\mathrm{V}$ & $\mathrm{Ba}$ & $\mathrm{Mo}$ & $\mathrm{Zn}$ & $\mathrm{Cu}$ & $\mathrm{Co}$ & $\mathrm{Cr}$ & $\mathrm{Ni}$ & $\mathrm{Cd}$ & $\mathrm{Pb}$ & $\mathrm{Sr}$ \\
\hline \multirow{2}{*}{ Проба 1 } & 250 & 163 & 992 & 4,8 & 45 & 7,0 & 10,5 & 22,5 & 26,2 & 0,10 & 22,5 & 243 \\
\cline { 2 - 14 } & 150 & 10 & 842 & 1,9 & 95 & 4,0 & 3,0 & 3,0 & 10,0 & 0,07 & 4,0 & 795 \\
\hline \multirow{2}{*}{ Проба 2 } & 83 & 15 & 178 & 2,7 & 15 & 4,2 & 1,5 & 10,2 & 5,5 & 0,03 & 7,0 & 82 \\
\cline { 2 - 13 } & 208 & 107 & 926 & 8,2 & 25 & 5,0 & 7,2 & 14,0 & 20,0 & 0,10 & 14,0 & 420 \\
\hline \multirow{2}{*}{ Проба 3 } & 75 & 10 & 46 & 1,9 & 17 & 3,0 & 1,5 & 1,5 & 2,5 & 0,02 & 2,2 & 24 \\
\cline { 2 - 12 } & 68 & 23 & 69 & 2,6 & 12 & 1,0 & 1,5 & 4,5 & 4,5 & 0,04 & 3,5 & 29 \\
\hline
\end{tabular}

При аварийных разливах нефти большая часть растительности торфяных болот погибает. Глубина проникновения нефти и нефтепродуктов зависит от плотности и мощности торфяного горизонта и достигает в среднем $10-15$ см. Тяжелые фракции нефти на торфяной залежи постепенно затвердевают, образуя битумообразную корку.

На некоторых участках месторождения при разведывательном бурении нефть, локализованную на дневной поверхности, сжигают. Токсичные и канцерогенные вещества, аккумулированные в нарушенных землях на месте сжигания разливов нефти, растворяются в воде и могут через гидросеть, дренирующую территорию, распространяться на значительные расстояния.

Экологическую опасность представляют отдаленные последствия сжигания нефтяных разливов и нефтяных попутных газов. Установлено, что на месте сжигания 1 тонны сырой нефти в нарушенной земле аккумулируется 75 г ванадия, 25 г никеля, 0,1-0,5 г бензапирена, токсичные концентрации кадмия, бериллия, мышьяка, марганца, свинца, кобальта и других химических элементов, ассоциированных с золой нефти. В каждом кубическом метре попутного нефтяного газа содержится несколько миллиграммов газообразной ртути, которая при сжигании нефтяного газа аккумулируется в образовавшейся золе и выпадает в форме твердых атмосферных осадков на земную поверхность.

Для решения геоэкологических проблем территории нефтедобычи необходимо применение альтернативных технологий использования и восстановления нефтезагрязненных земель, к которым относятся безамбарная технология бурения эксплуатационных скважин и использование модифицированного торфа для активизации микробиологических процессов биодеградации нефти [7].

\section{Заключение}

В результате проведенных исследований было выявлено, что к наиболее распространенным геоэкологическим проблемам нефтедобывающих районов Западной Сибири относятся технологические процессы эксплуатационного и разведывательного бурения нефтяных скважин, приводящие к загрязнению болотных комплексов.

Одним из источников поступления солей в ландшафты при нефтедобыче является содержимое шламовых амбаров, состоящее из отработанного бурового раствора, пластовых и поверхностных вод.

Результаты химического анализа техногенных загрязненных водных проб выявили высокое содержание хлоридов натрия, что явилось причиной щелочной реакции среды и, как следствие, гибели растительного покрова. Среди тяжелых металлов в асфальтеновых фракциях ароматических углеводородов высокое содержание характерно для $\mathrm{Ba}, \mathrm{Mn}$ и $\mathrm{Sr}$, которые относятся к 3 классу опасности. Накопление данных элементов может привести к гибели животных организмов.

Болота выполняют функцию ландшафтно-геохимических барьеров и способны аккумулировать большой спектр загрязняющих веществ. Поэтому для обеспечения экологической безопасности на производственно-технологических участках нефтедобычи возникает необходимость разработки иных, нежели сейчас применяются, критериев рекультивации торфяных болот.

\section{Список литературы / References}

1. Черданцев В.А., Цускман Е.И., Катункина Е.В., Дитц Л.Ю. Система экологического менеджмента как инструмент эффективного развития нефтегазодобывающей отрасли // Идеи и идеалы. 2015. Т. 2. № 3. С. 75-81.

Cherdantsev V.A., Tsuskman E.I., Katunkina E.V., Ditz L. Yu. Environmental management system as a tool for the effective development of the oil and gas industry // Ideas and Ideals. 2015. V. 2. № 3. P. 75-81 (in Russian).

2. Пичугин Е.А., Шенфельд Б.Е. К вопросу различия буровых и нефтяных шламов // Экология и про- 
мышленность России. 2017. Т. 21. № 7. С. 14-19. DOI: 10.18412/1816-0395-2017-7-14-19.

Pichugin E.A., Schoenfeld B.E. To the question of differences between drill and oil sludge // Ecology and Industry of Russia. 2017. V. 21. № 7. Р. 14-19 (in Russian).

3. Лопатин К.И., Женихов Ю.Н, Панов В.В., Толстограй В.И., Юсупов И.А. Проблемы территориального и технологического обустройства объектов нефтедобычи в условиях высокой заболоченности среднего Приобья // В книге: Геоэкологические основы использования торфяных болот и лесов Среднего Приобья. Тверь, 2012. С. 4-68.

Lopatin K.I., Zhenikhov Yu.N., Panov V.V., Tolstograi V.I., Yusupov I.A. Problems of territorial and technological arrangement of oil production facilities in conditions of high bogging of the middle Ob region // In the book: Geoecological basis for the use of peat bogs and forests of the Middle Ob. Tver, 2012. P. 4-68 (in Russian).

4. Добыча нефти. Информационно-технический справочник по наилучшим доступным технологиям. Федеральное агентство по техническому регулированию и метрологии. М.: Бюро НДТ, 2017. 273 с.

Oil production. Information and technical reference on the best available technologies. Federal Agency for Technical Regulation and Metrology. M.: Byuro NDT, 2017. 273 p. (in Russian).

5. Водяницкий Ю.Н., Аветов Н.А., Савичев А.Т., Трофимов С.Я., Шишконакова Е.А. Содержание химических элементов в торфяных почвах, засоленных буровыми сточными водами на участке добычи нефти в среднем Приобье // Агрохимия. 2013. № 1. С. 75-84.

Vodyanitsky Yu.N., Avetov N.A., Savichev A.T., Trofimov S.Ya., Shishkonakova E.A. The content of chemical elements in peat soils saline with drilling wastewater in the oil production area in the middle Priobye // Agrochemistry. 2013. № 1. P. 75-84 (in Russian).

6. Федорова О.С., Рязанова Т.В. Динамика микробиоценоза гетеротрофов в модельных опытах с применением биосорбента на основе смешанной бактериальной культуры // Системы. Методы. Технологии. 2017. № 1. С. 157-164. DOI: 10.18324/2077-5415-2017-1-157-164.

Fedorova O.S., Ryazanova T.V. Dinamics of heterotrophs microbiocenosis in model experiments with application of biosorbent on basis of mixed bacterial culture // Sistemy. Metody. Tekhnologii. 2017. № 1. Р. 157-164 (in Russian).

7. Лопатин К.И., Толстограй В.И., Женихов Ю.Н., Суворов В.И., Панов В.В. Альтернативная технология рекультивации нефтезагрязненных торфяных болот// Вестник Нижневартовского государственного гуманитарного университета. 2009. № 1. С. 58-61.

Lopatin K.I., Tolstograi V.I., Zhenikhov Yu.N., Suvorov V.I., Panov V.V. Alternative technology for the rehabilitation of oil-contaminated peat bogs // Vestnik Nizhnevartovskogo gosudarstvennogo gumanitarnogo universiteta. 2009. № 1. P. 58-61 (in Russian). 